IRA-International Journal of Applied Sciences ISSN 2455-4499; Vol.06, Issue 03 (2017)

Institute of Research Advances

Pg. no. 85-93

https://research-advances.org/index.php/IRAJAS



\title{
Estimation of Lovastatin in Pharmaceutical Formulation by Area under Curve Spectrophotometric Method
}

\author{
Dr. Shankar Dhobale ${ }^{1 \#}$, Vaibhav Narad $^{2}$, Dr. Dushyant Gaikwad ${ }^{3}$ \\ ${ }^{1,2,3}$ Vishal Institute of Pharmaceutical Education and Research, Ale, India.
}

\#Corresponding author.

Type of Review: Peer Reviewed.

DOI: http://dx.doi.org/10.21013/jas.v6.n3.p3

\section{How to cite this paper:}

Dhobale, S., Narad, V., \& Gaikwad, D. (2017). Estimation of Lovastatin in Pharmaceutical Formulation by Area under Curve Spectrophotometric Method. IRA-International Journal of Applied Sciences (ISSN 2455-4499), 6(3), 85-93. doi:http://dx.doi.org/10.21013/jas.v6.n3.p3

(C) Institute of Research Advances

\section{(c) EY-NC}

This work is licensed under a Creative Commons Attribution-Non Commercial 4.0 International License subject to proper citation to the publication source of the work.

Disclaimer: The scholarly papers as reviewed and published by the Institute of Research Advances (IRA) are the views and opinions of their respective authors and are not the views or opinions of the IRA. The IRA disclaims of any harm or loss caused due to the published content to any party. 


\begin{abstract}
Development of an accurate, simple and cost effective UV spectrophotometric method for estimation of Lovastatin was the aim of present study. This work was based upon an area under curve method i.e. "concentration of the component of interest is directly proportional to the area under two points on the mixture spectra". The UV spectrum between 238-258 $\mathrm{nm}$ was selected and the validation was carried out as per ICH guideline, Q2 (R1). This method obeyed Beer's Lamberts Law over the concentration range of $5-25 \mu \mathrm{g} \mathrm{ml}$. The value of correlation coefficient was 0.9988. The method was precise due to the satisfactory value of percent relative standard deviation for the intraday and inter-day precision. Result of the recovery studies (99.8) showed accuracy of method. Hence, developed method can be used for routine estimation of Lovastatin in bulk and dosage form.
\end{abstract}

Key Words: - Lovastatin; AUC; Validation; UV-Spectroscopy.

\title{
INTRODUCTION-(1)(2)
}

Lovastatin, a specific and potent competitive inhibitor of 3-hydroxy- 3-methyl glutaryl coenzyme A (HMG-CoA) is a powerful serum cholesterol-lowering drug in humans and other species. It is formerly called as mevinolin; monacolin $\mathrm{K}$, and mevacor® and it is a fungal secondary metabolite which inhibits HMG-CoA reductase (E.C 1.1.1.34), the first committed enzyme of cholesterol biosynthesis. The endogenous synthesis of cholesterol is carried out by the mevalonate pathway, in which the rate limiting reaction is the conversion of (S) HMG-CoA to (R) mevalonate, catalyzed by HMG-CoA reductase. The history of statin began in 1987 when the lovastatin received Food and Drug Administration (FDA) approval in the USA (Manzoni and Rollini 2002). Lovastatin have revolutionized the treatment of hypercholesterolemia and it is proven that lovastatin is also therapeutically and preventatively effective in the treatment of major kind of diseases like atherosclerosis, sepsis, peripheral arterial disease, peripheral vascular disease, cerebro vascular disease, ischemic disease, and bone fracture. Structure Lovastatin is [(1S,3R,7R,8aS)-8-[2-[(2R,4R)-4-hydroxy-6-oxooxan-2-yl]ethyl]-3,7-dimethyl-1,2,3,7,8,8a-

hexahydronaphthalen-1- yl](2S)-2methylbutanoate (IUPAC name). The empirical formula of lovastatin is $\mathrm{C} 24 \mathrm{H} 36 \mathrm{O} 5$ and molecular weight is 404.55 . Structure of Lovastatin is shown in Fig. 1.

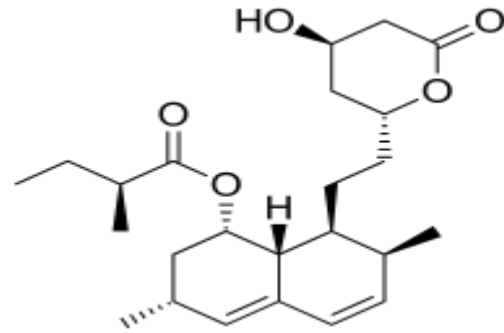

Fig. 1: Structure of Lovastatin

\section{MATERIALS AND METHODS \\ Material:-}

Lovastatin (API) was obtained as a gift sample from Greenlands, Ameerpet Road, Leelanagar, Ameerpet, Hyderabad, Telangana. A tablet formulation containing $10 \mathrm{mg}$ of Lovastatin (LOSTATIN) was purchased from local market, (Pashwanath Medical, Narayangaon, Pune). Mfg. by Dr.Reddy Laboratories.

Instruments Used:- 
A double beam UV-VIS spectrophotometer (UV-1800, Shimadzu) with spectra manager software UV Probe 2.21 was used. All weights were taken on electronic balance (Model Shimadzu AUX 120).

\title{
Method:-
}

\section{Preparation of Standard Solution}

Stock solution of $100 \mu \mathrm{g} / \mathrm{ml}$ of lovastatin was prepared by transferring an accurately weighed $10 \mathrm{mg}$ of Lovastatin into $100 \mathrm{ml}$ volumetric flask and diluted up to the mark with water.

\section{Selection of Wavelength Range-}

The standard solution of $10 \mu \mathrm{g} / \mathrm{ml}$ was scanned between $400 \mathrm{~nm}$ to $200 \mathrm{~nm}$ in UV spectrophotometer against water as a blank after baseline correction. The wavelength range was selected around wavelength maxima $(248 \mathrm{~nm})$.

\begin{abstract}
AREA UNDER CURVE-(3)
When there is no sharp peak or when broad spectra are obtained, The AUC (area under curve) method is usually applicable. This method consists of calculation of integrated value of absorbance with respect to the wavelength between the two selected wavelengths $\lambda_{1}$ and $\lambda_{2}$. Area calculation processing item calculates the area bound by the curve and the horizontal axis. The horizontal axis is selected by entering the wavelength range over which area has to be calculated. This wavelength range is selected on the basis of repeated observation so as to get the linearity between area under curve and concentration. The above mentioned spectrums were used to calculate AUC. Thus, the calibration curve can be constructed by plotting concentration versus AUC.
\end{abstract}

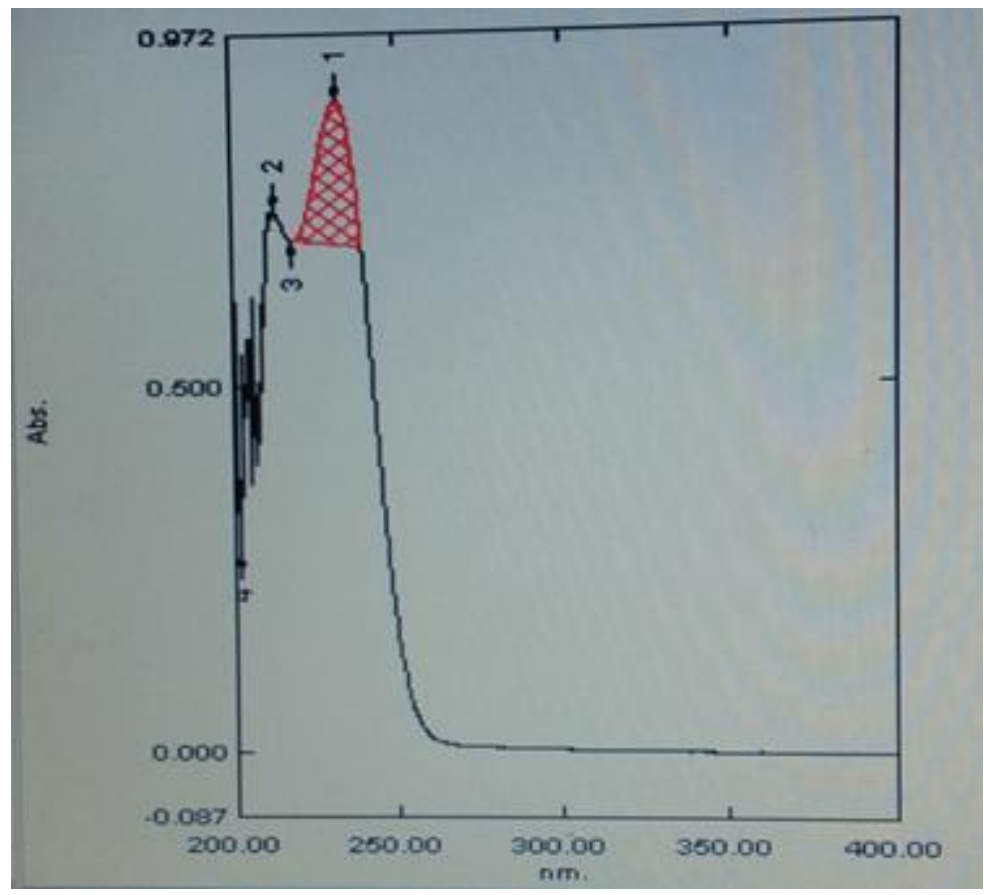

Fig.2 Spectrum of Lovastatin $(10 \mu \mathrm{g} / \mathrm{ml})$ 


\section{PREPARATION OF CALIBRATION CURVE}

Working solutions were prepared from standard stock solution by further dilution with water to obtain the concentration of $5,10,15,20$ and $25 \mu \mathrm{g} / \mathrm{ml}$ respectively. These solutions were scanned from 400 to $200 \mathrm{~nm}$ and area under curve was integrated in the range of $238-258 \mathrm{~nm}$. The calibration curve was plotted between areas under curve against concentration.

Table 1: Calibration data of Lovastatin for area under curve

\begin{tabular}{|c|c|c|}
\hline $\begin{array}{l}\text { Sr. } \\
\text { No }\end{array}$ & Concentration & AUC \\
\hline 1 & 5 & 0.983 \\
\hline 2 & 10 & 1.841 \\
\hline 3 & 15 & 2.791 \\
\hline 4 & 20 & 3.874 \\
\hline 5 & 25 & 5.101 \\
\hline
\end{tabular}

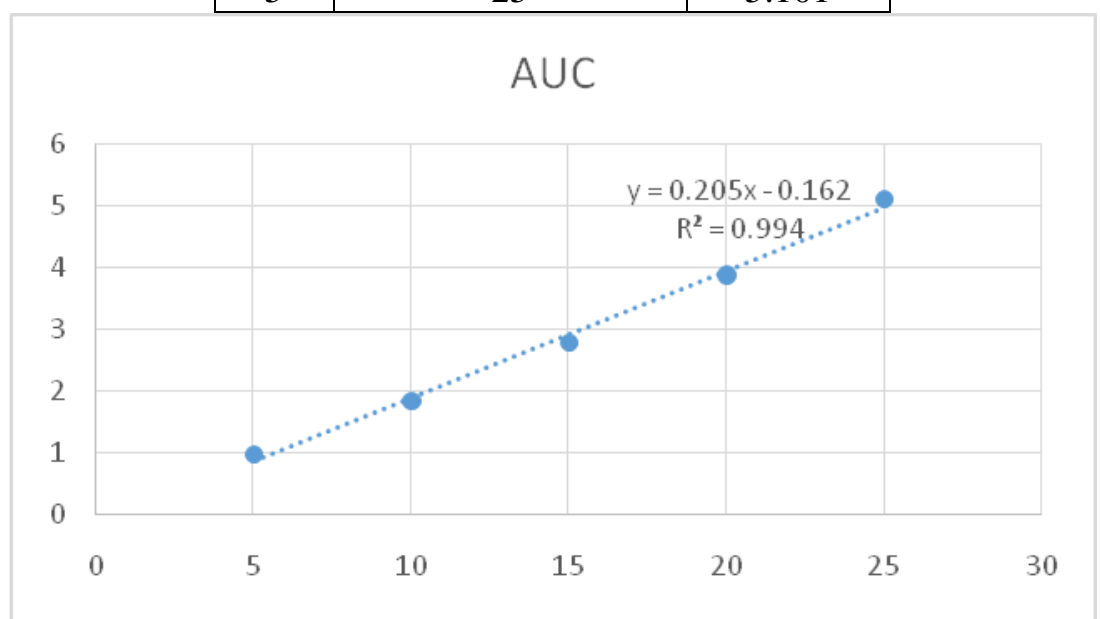

Fig.3 Calibration curve for AUC of Lovastatin.

Table 2: Analysis of Pure Drug

\begin{tabular}{|c|c|c|c|c|}
\hline Sr.no. & $\begin{array}{c}\text { Amount taken } \\
(\boldsymbol{\mu g} / \mathbf{m l})\end{array}$ & AUC & $\begin{array}{c}\text { Amount of } \\
\text { drug found }\end{array}$ & $\begin{array}{c}\text { \% amount } \\
\text { found }\end{array}$ \\
\hline 1 & 10 & 2.141 & 9.632 & 96.32 \\
\hline 2 & 10 & 2.099 & 9.428 & 94.28 \\
\hline 3 & 10 & 2.119 & 9.525 & 95.25 \\
\hline 4 & 10 & 2.171 & 9.778 & 97.78 \\
\hline 5 & 10 & 2.176 & 9.803 & 98.03 \\
\hline
\end{tabular}

Table 3: Statistical Evaluation of Pure Drug

\begin{tabular}{|l|l|l|}
\hline \% Mean & \pm SD & \%RSD \\
\hline 96.33 & 1.4395 & 1.49 \\
\hline
\end{tabular}

\section{ASSAY OF TABLET}

Twenty tablets (Lovastatin) containing $10 \mathrm{mg}$ of Lovastatin weighed, average weight calculated and triturated to fine powder and then weight equivalent $10 \mathrm{mg}$ of Lovastatin transferred into $100 \mathrm{ml}$ of volumetric flask and dissolved in water and diluted up to the mark with water to get a solution containing 
of $100 \mu \mathrm{g} / \mathrm{ml}$ from the $2.5 \mathrm{ml}$ was transferred to $25 \mathrm{ml}$ volumetric flask and diluted up to the mark with water to get lovastatin solution containing $10 \mu \mathrm{g} / \mathrm{ml}$ of Lovastatin.

Table 4: Analysis of Marketed Tablet

\begin{tabular}{|l|l|l|l|l|}
\hline $\begin{array}{l}\text { Sr. } \\
\text { No. }\end{array}$ & $\begin{array}{l}\text { Amount Taken } \\
(\boldsymbol{\mu g} / \mathbf{m l})\end{array}$ & AUC & $\begin{array}{l}\text { Amount of } \\
\text { drug found }\end{array}$ & $\begin{array}{l}\text { \%amount } \\
\text { found }\end{array}$ \\
\hline 1 & 10 & 1.543 & 10.39 & 103.9 \\
\hline 2 & 10 & 1.539 & 10.35 & 103.5 \\
\hline 3 & 10 & 1.534 & 10.31 & 103.1 \\
\hline 4 & 10 & 1.544 & 10.40 & 104.0 \\
\hline 5 & 10 & 1.599 & 10.89 & 108.9 \\
\hline
\end{tabular}

Table 5: Statistical evaluation of marketed drug

\begin{tabular}{|l|l|l|}
\hline \% Mean & 土SD & \%RSD \\
\hline 104.68 & 2.1339 & 2.03 \\
\hline
\end{tabular}

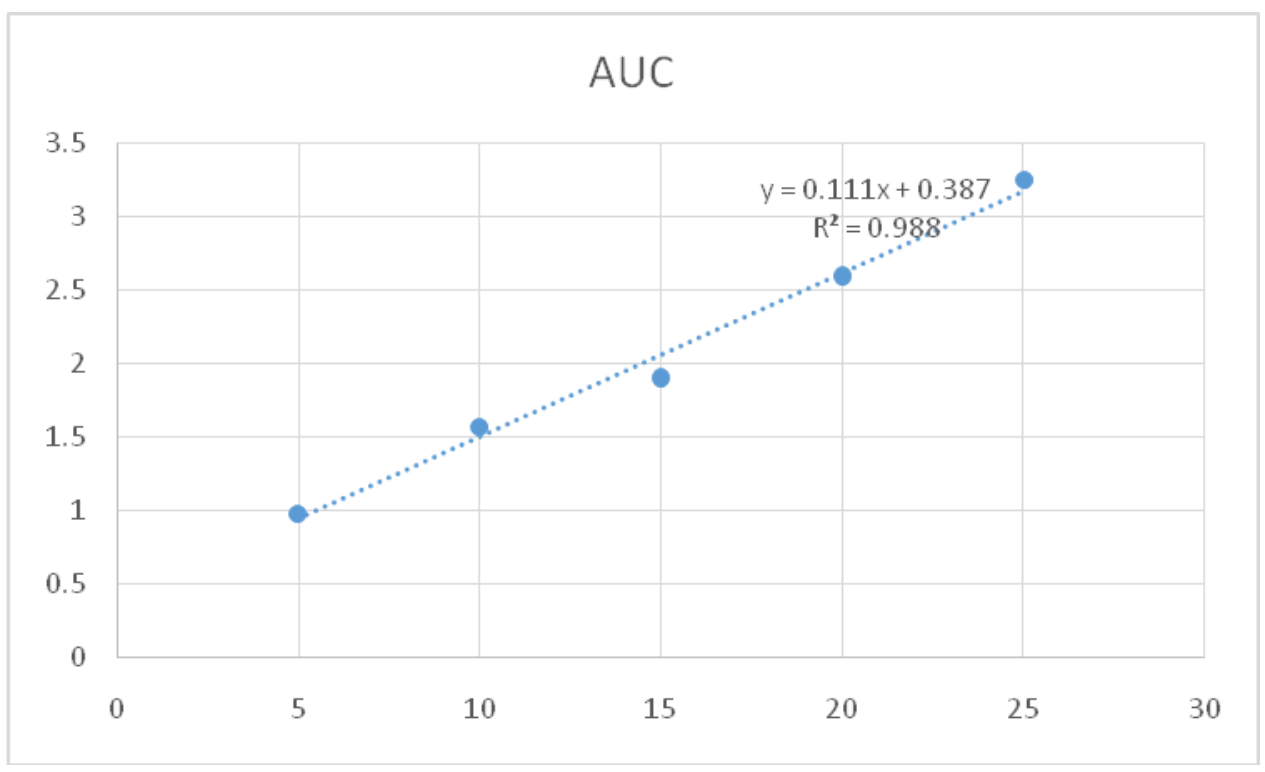

Fig.:4 Calibration Curve of Lovastatin tablet

Table 6: Calibration Data of marketed tablet

\begin{tabular}{|l|l|l|}
\hline $\begin{array}{l}\text { Sr. } \\
\text { No. }\end{array}$ & Concentration & AUC \\
\hline 1 & 5 & 0.976 \\
\hline 2 & 10 & 1.564 \\
\hline 3 & 15 & 1.900 \\
\hline 4 & 20 & 2.593 \\
\hline 5 & 25 & 3.241 \\
\hline
\end{tabular}




\section{VALIDATION:-(4)}

The developed method was validated as per ICH guidelines.

\section{Linearity}

The linearity was determined by using working standard solution between $5-25 \mu \mathrm{g} / \mathrm{ml}$. The spectrums of thissolution were recorded and integrated at wavelength range $248 \mathrm{~nm}$. Calibration curve of Conc. Vs AUC was plotted after suitable calculation and simple linear regression was performed.

\section{Precision}

The precision of the method was checked by repeatedly injecting 5-15 $\mu \mathrm{g} / \mathrm{ml}$. Absorbance of each of these solutions was measured at the $248 \mathrm{~nm}$. Percent relative standard deviation (RSD) was calculated.

\section{Accuracy}

The accuracy for the analytical procedure was determined at $80 \%, 100 \%$ and $120 \%$ level of standard solution. Absorbance was measured at the range $248 \mathrm{~nm}$ and result was expressed in term \% recoveries. Three determinations at each level were performed and \%RSD was calculated.

\section{Sensitivity}

The International Conference on Harmonization (ICH) [16] guidelines on determination of limit of detection (LOD) and limit of quantitation (LOQ) define LOD as $3 \mathrm{~s} / \delta$ while LOQ as $10 \mathrm{~s} / \delta$, where $\mathrm{s}$ is the standard deviation of replicate determination values under the same conditions as for the sample analysis in the absence of the analytes and $\delta$ is the sensitivity, the slope of the calibration curve.

\section{RESULT AND DISCUSSION}

The calibration curve of Lovastatin was performed and graph plotted concentration versus area under curve.

Table 7: Interday and Intraday precision

\begin{tabular}{|l|l|l|}
\hline $\begin{array}{l}\text { Sr. } \\
\text { No. }\end{array}$ & Parameter & Result \\
\hline 1 & Intra- day Precision & \\
\hline & Added $(\mu \mathrm{g} / \mathrm{ml})$ & 10 \\
\hline & $\%$ RSD & 3.17 \\
\hline & SD & 0.017 \\
\hline & Accuracy $(\%$ recovery $)$ & 98.73 \\
\hline 2 & Interday Precision & \\
\hline & Added $(\mu \mathrm{g} / \mathrm{ml})$ & 10 \\
\hline & $\%$ RSD & 3.30 \\
\hline & SD & 0.012 \\
\hline & Accuracy $(\%$ recovery $)$ & 108 \\
\hline
\end{tabular}


Table 8: RESULT OF RECOVERY STUDIES

\begin{tabular}{|c|c|c|c|c|c|}
\hline $\begin{array}{c}\text { Sr. } \\
\text { No. }\end{array}$ & $\begin{array}{c}\text { Concentration } \\
\text { Taken }(\boldsymbol{\mu g} / \mathbf{m l})\end{array}$ & $\begin{array}{c}\text { Concentration } \\
\text { Added }\end{array}$ & $\begin{array}{c}\text { \% Concentration } \\
\text { added }\end{array}$ & Absorbance & $\begin{array}{c}\text { \% } \\
\text { Recovery }\end{array}$ \\
\hline 1 & 10 & 0.8 & 80 & 0.778 & 77.8 \\
\hline 2 & 10 & 0.8 & 80 & 0.784 & 78.4 \\
\hline 3 & 10 & 0.8 & 80 & 0.798 & 79.8 \\
\hline 4 & 10 & 1.0 & 100 & 0.978 & 97.8 \\
\hline 5 & 10 & 1.0 & 100 & 0.986 & 98.6 \\
\hline 6 & 10 & 1.0 & 100 & 0.998 & 99.8 \\
\hline 7 & 10 & 1.2 & 120 & 1.17 & 117 \\
\hline 8 & 10 & 1.2 & 120 & 1.18 & 118 \\
\hline 9 & 10 & 1.2 & 120 & 1.19 & 119 \\
\hline
\end{tabular}

\section{ANALYSIS OF PURE DRUG}

The standard solution of $10 \mu \mathrm{g} / \mathrm{ml}$ was scanned between $400-200 \mathrm{~nm}$ in UV spectrophotometer against methanol as a blank after baseline correction. The area Under Curve of Solution was measured.

\section{Statistical Evaluation of Pure Drug :-}

Statistical Evaluation of Pure Drug is shown in Table No.3.

\section{ANALYSIS OF MARKETED FORMULATION}

Twenty Tablets (lostatin) containing 10mg of lovastatin weighed, average weight calculated and Triturated to fine powder, then weighed equivalent to $10 \mathrm{mg}$ of lovastatin and transferred to the $100 \mathrm{ml}$ of volumetric flask and dissolved into methanol. Diluted up to the mark with methanol to get solution containing $100 \mu \mathrm{g} / \mathrm{ml}$. From this, $2.5 \mathrm{ml}$ was transferred to the $25 \mathrm{ml}$ volumetric flask and diluted up to the mark with methanol to get Lovastatin solution containing $10 \mu \mathrm{g} / \mathrm{ml}$ of Lovastatin and results were obtained.

\section{Statistical Evaluation of Marketed Formulation}

Table 5 shows statistical evaluation of marketed formulation.

\section{VALIDATION}

\section{Linearity}

Calibration curve of area under curve versus concentration was plotted after suitable calculation and simple linear regression was performed and results were shown in Table 1 and Fig.2.The regression equation obtained is $\mathrm{y}=0.2054 \mathrm{x}-0.1624$. and $\mathrm{R}^{2}=0.9949$.

\section{Precision}

Percent relative standard deviation (RSD) was calculated and results are shown in Table 7.

The \%RSD for the Intraday and Interday was found to be 3.17 and 3.30 respectively. 


\section{Accuracy}

The \% recovery was obtained between the 98.73 to 108 as shown in table no. 8 .

Table No.9: Summary Data Of the Validation Parameter

\begin{tabular}{|l|l|l|}
\hline $\begin{array}{l}\text { Sr. } \\
\text { No. }\end{array}$ & Parameter & Observation \\
\hline 1 & Linearity Range & $5-25$ \\
\hline 2 & Regression Equation & $\mathrm{Y}=0.2054-0.1624$ \\
\hline 3 & Correlation coefficient & $\mathrm{R}^{2}=0.9949$ \\
\hline 4 & Precision & \\
& - Intraday & 3.17 \\
& - Interday & 3.30 \\
\hline 5 & \% Recovery & $98.73-108$ \\
\hline
\end{tabular}

\section{DISCUSSION}

An attempt was made to develop a simple and specific AUC spectrophotometric method for the determination of Lovastatin in tablet dosage form. The generated regression equation was $\mathrm{y}=0.2054 \mathrm{x}-$ $0.1624\left(\mathrm{R}^{2}=0.9949\right)$. The AUC between $238-258 \mathrm{~nm}$, $\mathrm{x}$ is the concentration and $\mathrm{R}$ is correlation Coefficient. The $\mathrm{R}^{2}$ value 0.9949 , indicates that developed method was linear.

The proposed method was found to be precise, \% RSD value for interday and intraday precision were satisfactory. The drug has good recoveries (99.8\%). Hence, it can be said that this method is accurate.

The result of analysis of formulation by developed method was consistent with labeled claim, highly reproducible and reliable.The method can be used for routine analysis of Lovastatin. The validation parameters are summarized in table no.9.

\section{CONCLUSION}

No any spectrophotometric methods have been described for AUC estimation of Lovastatin. Therefore, simple, fast and reliable area under curve spectrophotometric method was developed for routine analysis of Lovastatin. The developed method can be concluded as accurate, sensitive and precise and be easily applied to the pharmaceutical formulation.

\section{REFERENCES}

1. A review on lovastatin and its production Goswami S, Vidyarthi AS, Bhunia B, Mandal T* J Biochem Tech (2012) 4(1): 581-587 ISSN: 0974-2328

2. Seraman S, Rajendran A, Thangavelu V (2010) Statistical optimization of anticholesterolemic drug lovastatin production by the red mold Monascus purpureus. Food and bioproducts processing, 88: 266-276.

3. Connors K A. A textbook of pharmaceutical analysis, 3rd edition, John Wiley and Sons, USA, 221-224, 1982.

4. ICH, Q2A. Text on validation of analytical procedures: methodology, International Conference on Harmonization, Geneva, 1-8, 1996.

5. Beckett A H, Stenlake J B. Practical Pharmaceutical Chemistry,4th edition, CBS Publishers and Distributors, New Delhi, 2:275-295, 2002. 
6. Ishikawa-machi, Hachioji-shi. Instruction Manual User's System Guide UV-530 Visible Spectrophotometer (Double Beam), Jasco, Japan, 2967-5, 2000.

7. USP NF Volume - 2, 2009,Page no.-731-736.

8. Willard H H, Merritt JrLyne L, Dean John A, Settle, Jr Frank A, Instrumental Methods of Analysis, 7th edition, CBS Publishersand Distributors pvt.Ltd, New Delhi, 2-5, 1998.

9. Skoog, Holler, Nieman. Principles of Instrumental Analysis, $5^{\text {th }}$ edition, ThomsonAsia PvtLtd, Singapore, 300-325, 2004.

10. Chatwal G R, Anand S K. Instrumental methods of chemical analysis, 5th edition, Himalaya Publishing House, Mumbai, 1.1-1.5,2.108-2.109, 2005. 